\title{
Effects of Myo-Inositol and Thiamine on Micropropagation of GF677 (Peach $\times$ Almond Hybrid)
}

\author{
Sadegh Sepahvand (Corresponding author) \\ Graduate student, Azad University of Tehran, Science and Research Branch, Tehran, Iran \\ Tel: 98-912-683-1371 E-mail: Sa.sepah@gmail.com
}

Ali Ebadi

Professor, University College of Agriculture \& Natural Resources of Tehran, Karaj, Iran

Tel: 98-912-567-7521_E-mail: Ebadi@ut.ac.ir

Kazem Kamali

Assistant Professor, Department of Environmental Engineering

Faculty of Natural Resources and Desert Studies, Yazd University, Yazd, Iran

Tel: 98-913-352-5822_E-mail: kamali100in@yahoo.com

Saeid Ali Ghaemmaghami

Instructor, Agricultural Institute, Iranian Research Organization for Science \& Technology (IROST)

Tehran, Iran

Tel: 98-912-148-8705 E-mail: Ghaemmaghami@irost.org

Received: June 20, $2011 \quad$ Accepted: June 27, $2011 \quad$ Online Published: December 21, 2011

doi:10.5539/jas.v4n2p275 URL: http://dx.doi.org/10.5539/jas.v4n2p275

\begin{abstract}
GF677 is a vigorous rootstock, used for both peach and almond worldwide. Nowadays, it is propagated is mainly through micro propagation. Widening and undesirable growth of leaves as well as poor rooting are major problems during its in vitro culture. In this study, effects of myo-inositol at 10 and $100 \mathrm{mg} / \mathrm{ln}$ MS medium were studied at explants establishment and shoot growth stages. Thiamine was also used in LS medium at 0, 1.6, 2.8 and $4 \mathrm{mg} / \mathrm{l}$ at rooting stage. This experiment was conducted in Randomized Complete Design with 10 replications. Myo-inositol at 10mg/l could prevent undesirable widening of leaves as well as rosetting of shoots. Thiamine at $1.6 \mathrm{mg} / \mathrm{l}$ was highly effective in rooting of shoots.
\end{abstract}

Keywords: Myo-Inositol, Thiamine, In vitro propagation, Leaf widening, Rooting, GF677

\section{Introduction}

Gf677 is a major rootstock for both peach and almond, widely used in many countries. It was discovered in 1940 (Stylianidas et al., 1988). At first, it was noticed due to its tolerance to calcareous soils and later by developing tissue culture techniques, it became a dominant rootstock for peach in France (Rom and Carlson, 1987). Gf677 is a vigorous rootstock (Loreti et al., 1985; Maragoni et al., 1985), which is tolerant to chloresis induced by high soil lime (Syrgiannidis, 1985; Bindra, 1975). Grafted tree on this rootstock is vigorous and productive (Maragoni et al., 1985; Minguzzi, 1989). GF677 is also tolerant to drought and has moderate resistance to some diseases (Rom and Carlson, 1987). Furthermore, it is compatible with most almond and peach cultivars (Grassely, 1987). Sexual propagation of this rootstock resulted in segregation and producing of non-uniform seedlings. To prevent this problem, it is propagated by asexual methods (Rom and Carlson, 1987). 
Asexual propagation of GF677 is difficult and its micropropagation is encountered by vitrification, shoot rosetting and low rooting (Tsipouridis et al., 2003). Miller et al. (1982) used different media with and without vitamin in the rooting stage. Results showed that vitamin had significant effect on rooting ability of shoots. Effects of myo-inositol and cytokinin on rooting of GF677 explants were studied. Results showed that myo-inositol accelerates BA transport to different parts of plant. Kas et al. (2004) compared MS and $1 \frac{2}{2}$ MS for in vitro propagation of GF677 and concluded that $1 / 2$ MS medium was more convenient and prevented abnormal shoot growth which was observed in MS medium. Tsiporidis et al. (2003) compared different media for in vitro propagation of GF677 and eventually introduced $1 / 2$ MS and Knop as more suitable media compared to MS medium.

In this study, effects of myo-inositol were studied on prevention of rosetting and leaf expansion during explants establishment, shoot proliferation and shoot growth as well as the effect of thiamine on rooting.

\section{Methods and Materials}

\subsection{Plant materials}

Explants were collected at mid May 2010. Shoots with length of 15-20 cm were cut off and transferred to laboratory. Shoots were washed with tap water, and then were cut off to pieces of three $\mathrm{cm}$ length, each including one bud. Explants were sterilized with $0.1 \%$ mercury chloride for $3.5 \mathrm{~min}$. Later, they were washed twice with double distillated water containing citric acid $700 \mathrm{mg} / \mathrm{l}$ (Fig. 1).

\subsection{Growth conditions}

Explants were cultured in different media and then grown in growth room with light intensity of 2500-3000 lux, photoperiod of $16 / 8$ hours light/dark, relative humidity of $45 \%$ and constant temperature of $25 \pm 1{ }^{\circ} \mathrm{C}$. McCarthy glasses were used for the establishment stage of explants.

MS and modified MS (with $10 \mathrm{mg} / 1$ myo-inositol) containing $0.1 \mathrm{mg} / 1 \mathrm{BA}, 7 \mathrm{~g} / \mathrm{l}$ agar and $30 \mathrm{~g} / 1$ sucrose (pH was adjusted on 5.7) were used.

Subculture was carried out after one month, and then explants were transferred to proliferation medium. After proliferation, small shoots were transferred to MS media containing 10 or $100 \mathrm{mg} / \mathrm{l}$ myo-inositol as well as agar $7 \mathrm{mg} / \mathrm{l}$, sucrose $30 \mathrm{~g} / \mathrm{l}$ and BA $0.1 \mathrm{mg} / \mathrm{l}$ (pH was adjusted on 5.7), in which shoot growth was completed within three weeks. Shoots with 5-6 cm length were transferred to LS rooting media (Fig. 2), in which, IBA was used at concentrations of $0,1,1.3,1.6$ and $1.9 \mathrm{mg} / \mathrm{l}$, thiamine at concentrations of $0,1.6,2.8$ and $4 \mathrm{mg} / 1, \mathrm{Fe}-\mathrm{EDDHA}$ at $100 \mathrm{mg} / \mathrm{l}$, agar at $7 \mathrm{~g} / \mathrm{l}$ and sucrose at $30 \mathrm{~g} / \mathrm{l}(\mathrm{pH}$ was adjusted on 5.7). Cultures were kept in dark for seven days and then transferred to light (2000-2500 lux). During rooting period, temperature was set at $23 \pm 1{ }^{\circ} \mathrm{C}$. Rooting was initiated after eight days and completed after six weeks. Rooting percentage, root number and root length were recorded. This experiment was conducted as factorial in Randomized complete Design with 20 replications. Data was analyzed with SAS software.

\section{Results and Discussion}

\subsection{Effect of myo-inositol on shoot growth}

Different media have different effects on shoot growth due to their different concentrations of nutrients. At establishment stage, there is a problem in which leaves get large and wide due to high carbon sources in MS medium, which ends in dwarf and rosette shoots. In this work, decreasing the level of myo-inositol from 100 $\mathrm{mg} / 1$ to $10 \mathrm{mg} / \mathrm{l}$ resulted in normal shoot growth. Mean comparison showed that the highest shoot length $(4.6 \mathrm{~cm})$ was obtained in modified MS with only $10 \mathrm{mg} / 1$ myo-inositol (Fig. 3). This treatment increased shoot growth, leaving no sign of rosetting (Fig. 4).

\subsection{Effect of thiamine on rooting}

Thiamine and IBA had significant effects on rooting percentage in such a way that even lower concentrations of thiamine caused increment of rooting in all IBA levels. Rooting percentage was also influenced by interaction between thiamine and IBA (Table 1). The lowest percent of rooting occurred in LS medium without thiamine. However, the highest rooting percentage were obtained in LS medium with thiamine at $1.6 \mathrm{mg} / \mathrm{l}, \mathrm{IBA}$ at $1,1.3$ and $1.6 \mathrm{mg} / \mathrm{l}$ or thiamine at $2.8 \mathrm{mg} / \mathrm{l}, \mathrm{IBA}$ at 1.3 and $1.6 \mathrm{mg} / \mathrm{l}$ (Fig. 5 ).

Number of roots/shoot was also affected by thiamine, IBA and their interaction. Thiamine at 1.6 and $2.8 \mathrm{mg} / 1$ produced the highest number of roots. However, its application at $4 \mathrm{mg} / \mathrm{l}$ or even control had the lowest number of roots. IBA at 1.3 or $1.6 \mathrm{mg} / \mathrm{l}$ both produced the highest number of roots. The lowest number of roots was obtained in control. 
Length of roots was also affected by thiamine in which application of thiamine at $1.6 \mathrm{mg} / \mathrm{l}$ produced the longest root and control had the shortest root. IBA at 1.3 and $1.6 \mathrm{mg} / 1$ produced the longest roots, but its application at 1 and $1.9 \mathrm{mg} / 1$ significantly resulted in shorter roots. The highest root length was observed in treatment with no IBA application and lowest root length were obtained with IBA application at $1.9 \mathrm{mg} / \mathrm{l}$, indicating the negative effect of IBA on root length.

Application of thiamine in LS medium had a great effect on root number and length, but increasing its amount to $4 \mathrm{mg} / \mathrm{l} \mathrm{had} \mathrm{reductive} \mathrm{effect} \mathrm{on} \mathrm{root} \mathrm{number} \mathrm{and} \mathrm{there} \mathrm{were} \mathrm{no} \mathrm{significant} \mathrm{effect} \mathrm{between} \mathrm{thiamine} \mathrm{at} 4 \mathrm{mg} / \mathrm{l}$ and control. Thiamine as an enzyme cofactor has important effect on metabolically reactions such as glycolysis or in pentose phosphate and tricarboxilic acid cycle. In addition to thiamine value as a nutritional compound, it is also secondary messenger in activation of proteins with low molecular weight. Thiamine also causes increment in expression of genes involved in producing defective enzymes which increase plant resistance to plant pathogens (Hwanlee and Soonok, 2005). Interaction between IBA and thiamine (Fig. 6) showed that in LS medium the highest root number was obtained with thiamine at $1.6 \mathrm{mg} / \mathrm{l}$ and IBA at $1.3 \mathrm{mg} / \mathrm{l}$. IBA at $1.9 \mathrm{mg} / \mathrm{l}$ together with different levels of thiamine had reductive effect on root number. With no application of thiamine, root number/shoot correlated with IBA levels and highest root number was obtained with IBA at $1.9 \mathrm{mg} / \mathrm{l}$. Thiamine and IBA interaction showed that the highest root length belonged to control, but its lowest amount resulted with IBA at $1.9 \mathrm{mg} / \mathrm{l}$ and with no thiamine (Fig. 7).

Results of this experiment showed that myo-inositol application at $10 \mathrm{mg} / \mathrm{l}$ could be a solution to shoot rosetting and abnormal largening of leaves. In addition, application of thiamine at $1.6 \mathrm{mg} / \mathrm{l}$ and IBA at $1.3 \mathrm{mg} / \mathrm{l}$ resulted in the highest rooting of GF677 in vitro conditions. Therefore, the modified MS medium was best for establishment of GF677 explants and also for normal shoot growing. However, for rooting, LS medium with $1.6 \mathrm{mg} / \mathrm{l}$ thiamine and $1.3 \mathrm{mg} / 1 \mathrm{IBA}$ were proved to be best options.

\section{References}

Arye, G., Arie, A., Rsfael, S., Tomy, S. \& Brenda, W. (2006). Interactions between myo-inositol and cytokinins: Their basipetal transport and effect on peach rootstock. J. Physio. Planta., 69, 633-638.

Bindro, A. S. (1975). Inducing resistance to iron-deficiency chlorosis in peach-plants through the use of suitable rootstocks. J. of Research, 14, 38-40.

Bonga, J. M. \& Durzan, D. J. (1982). Tissue culture in forestry the Hague: Martinus Nijhoff. Publishers, Netherland.

Briat, J. F., Lobreaux, S. (1997). Iron transport and storage in plants. Trends Plant Sci., 2, 187-193. http://dx.doi.org/10.1016/S1360-1385(97)85225-9

Cos, J., Frutos, D., Sanchez, M. A., Rodriguez, J. \& Carrillo, A. (2004). Determination of the optimal culture medium and growth regulator concentration for the vitro proliferation stage of the peach-almond hybrid mayor. Acta Hort., 658, 617-622.

Grassely, C. (1987). New French stone fruit rootstocks. Fruit Varieties Journal, 41, 65-67.

Hwan lee, Y. \& Soonok, K. (2005). Vitamin $B_{1}$ functions as an Activa of plant disease resistance. Plant Physiol., $138,1505-1515$.

Loreti, F., Morini, S. \& Grilli, A. (1985). Rooting response of $\mathrm{PSB}_{2}$ and GF677 rootstock cuttings. Acta Hort., 173, 261-269.

Isikalan, C., Akbas, F. A., Namli, S., Tilkat, E. \& Basaran, D. (2004). In vitri micropropagation of almond (Amygdalus communis L. cv. Nonpareil). Afric. J. Biotech., 7, 1875-1880.

Maragoni, B., Antonelli, M., Scudellari, D. \& Liverani, A. (1985). The behavior of cv 'Redhaven' on different rootstocks. Acta Hort., 173, 389-394.

Miller, G. A., Coston, D. C., Denny, E. G. \& Romeo, M. E. (1982). In vitro propagation of nemagaurd peach rootstock. Hort. Sci., 17, 94.

Minguzzi, A. (1989). Rootstock effects on peach replanting: A ten years trial. Acta Hort., 254, 357-361.

Rom, C. R. \& Carlson, R. F. (1987). Rootstocks for fruit crops. John Wiley \& Sons.

Romheld, V., Marschner, H. (1981). Iron deficiency stress induce morphological and physiological changes in root tips of sunflower. Physiol. Plant, 53, 354-360. http://dx.doi.org/10.1111/j.1399-3054.1981.tb04512.x 
Sotiropoulos, T. E. \& Fotopoulos, S. (2005). In vitro propagation of the PR204/84 peach rootstock (Prunus persica $\times P$. amygdalus): The effect of $\mathrm{BAP}, \mathrm{GA}_{3}$, and activated charcoal on shoot elongation. Europ. J. Hort. Sci., 70, 253-255.

Styliandes, D. C., Syrgianidis, G. D. \& Almaliotis, D. D. (1988). The peach rootstocks: A review of bibliography with relative observations in Greece. Agri. Tech., 12, 34-69.

Syrgiannidis, G. (1985). Control or iron chlorosis and replant diseases in peach by using the GF677 rootstock. Acta Hort., 173, 383-388.

Tsipouridis, C. \& Thomidis, T. (2003). Methods to improve the in vitro culture of GF677 (peach $\times$ almond) peach rootstock. New Zealand J. Crop Hort. Sci., 31, 361-364. http://dx.doi.org/10.1080/01140671.2003.9514272

Table 1. The Analysis of variance of rooting percentage, root number and root length under effect of thiamine and IBA application

\begin{tabular}{|c|c|c|c|c|}
\hline \multirow{2}{*}{ Source of Variation } & \multirow{2}{*}{ df } & \multicolumn{3}{|c|}{ Mean Squares } \\
\cline { 3 - 5 } & & Root percentage & Root number & Root length \\
\hline Thiamine & 3 & $3.830^{* *}$ & $71.424^{* *}$ & $67.697^{* *}$ \\
\hline IBA & 4 & $5.1663^{* *}$ & $88.725^{* *}$ & $108.424^{* *}$ \\
\hline Thiamine× IBA & 12 & $0.4112^{* *}$ & $13.711^{* *}$ & $5.339^{* *}$ \\
\hline Error & 380 & 0.1255 & 3.526 & 0.7462 \\
\hline
\end{tabular}

**: significant difference at $\% 1$ probability level.

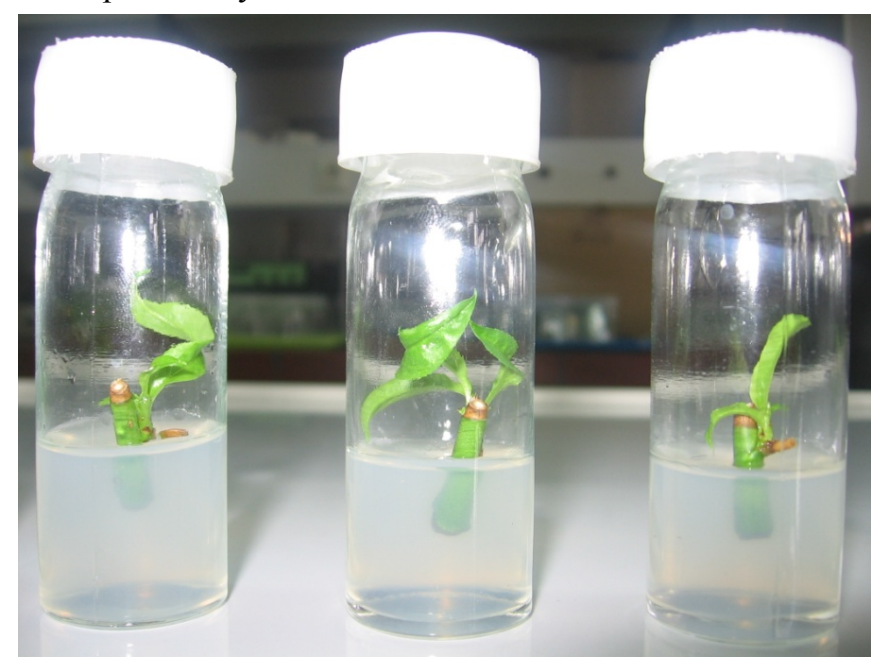

Figure 1. Establishment of GF677 explants

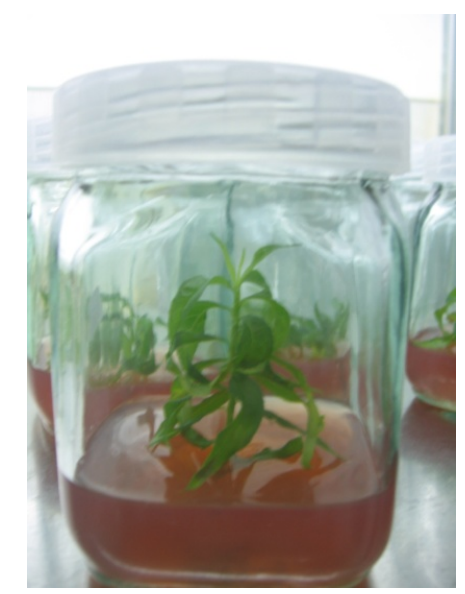

Figure 2. GF677 shoots at rooting medium 


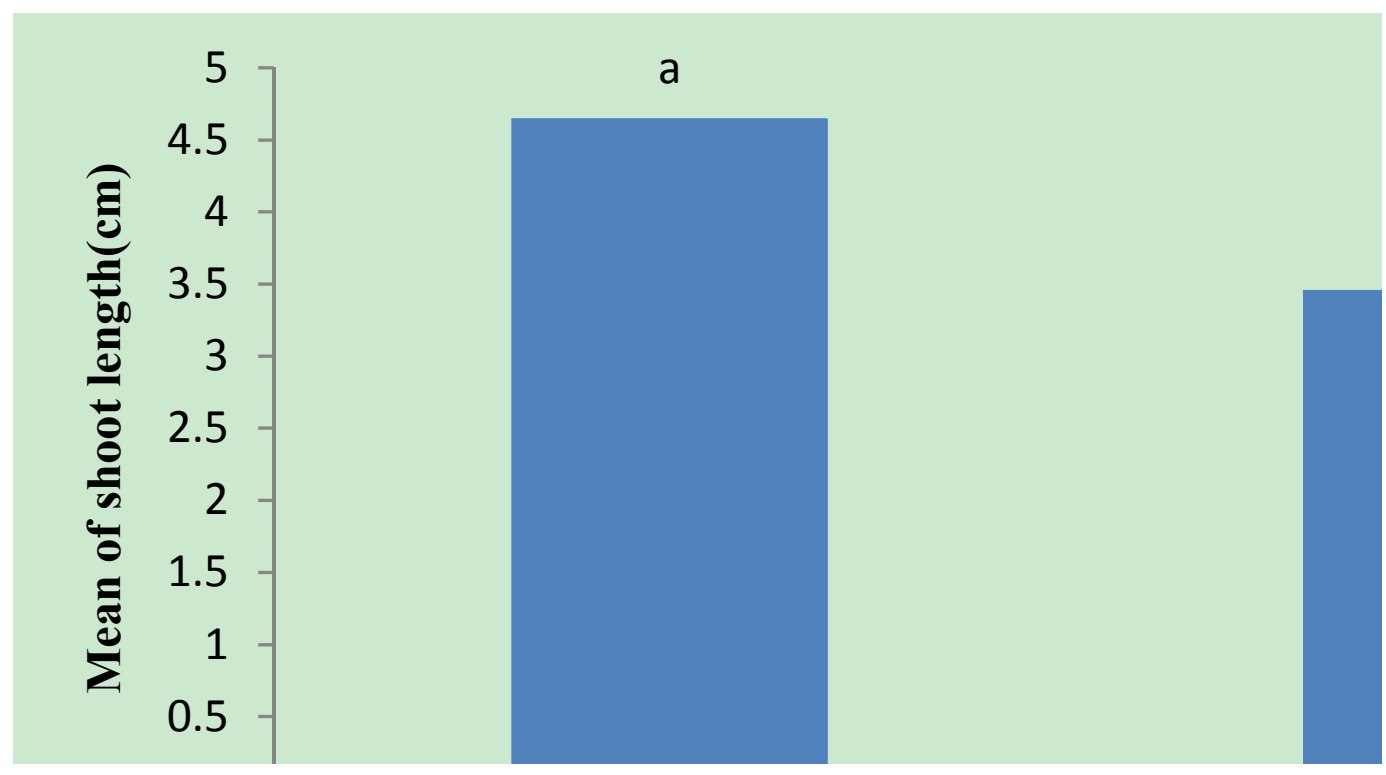

Figure 3. The Effect of myo-inositol on shoot growth of GF677.

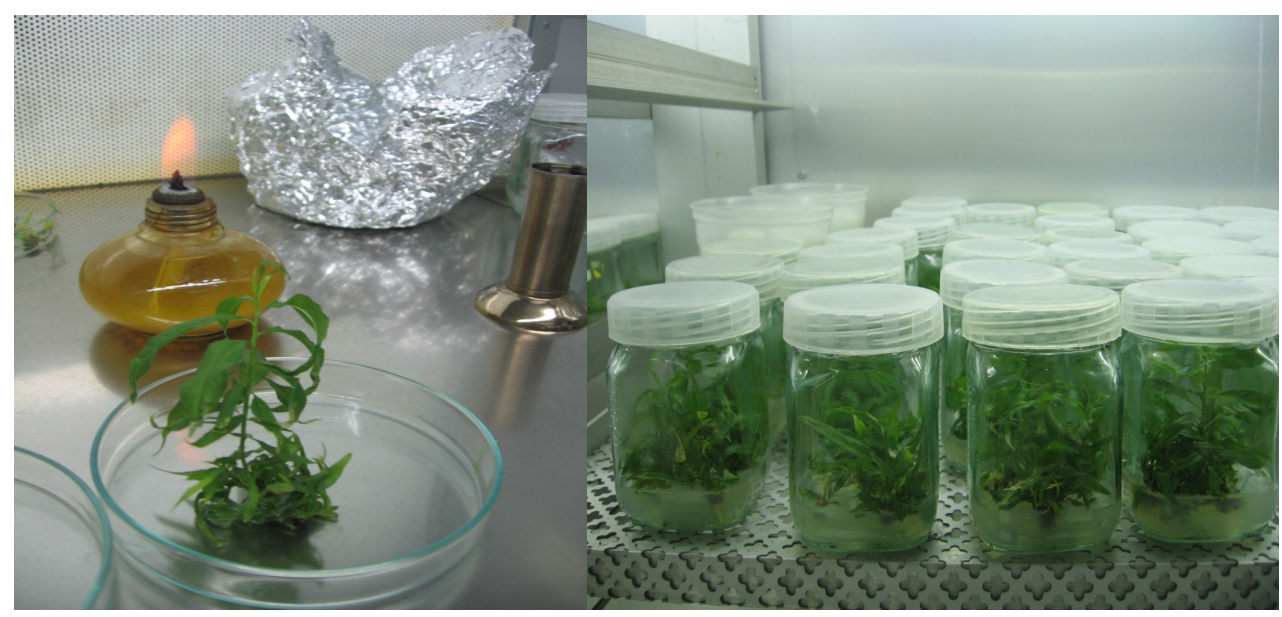

Figure 4. The Effect of myo-inositol on shoot length

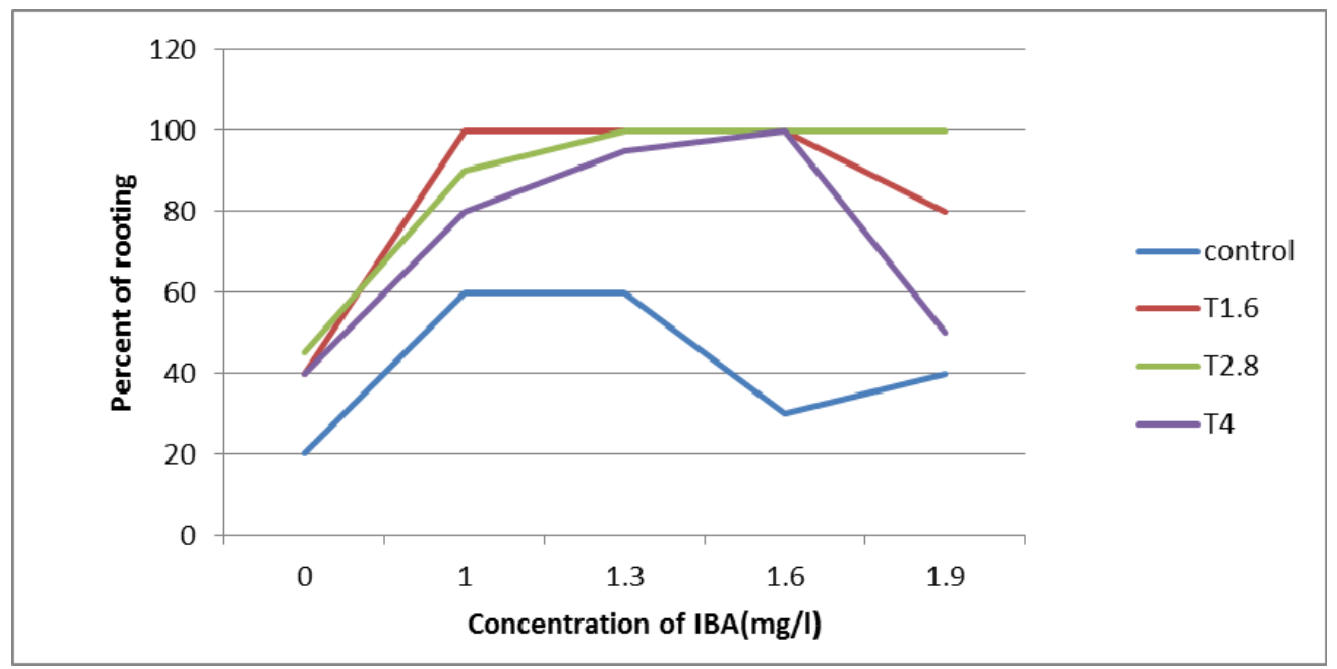

Figure 5. The Effect of different levels of thiamine and IBA on percent of rooting 


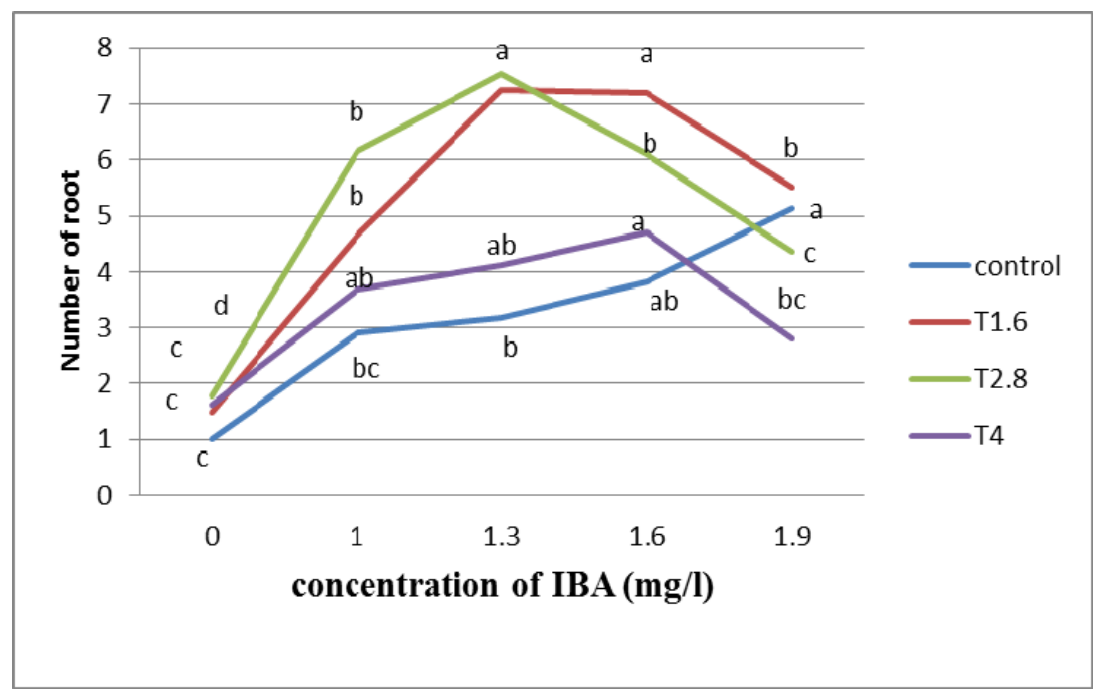

Figure 6. The Effect of thiamine and IBA on root number of GF677

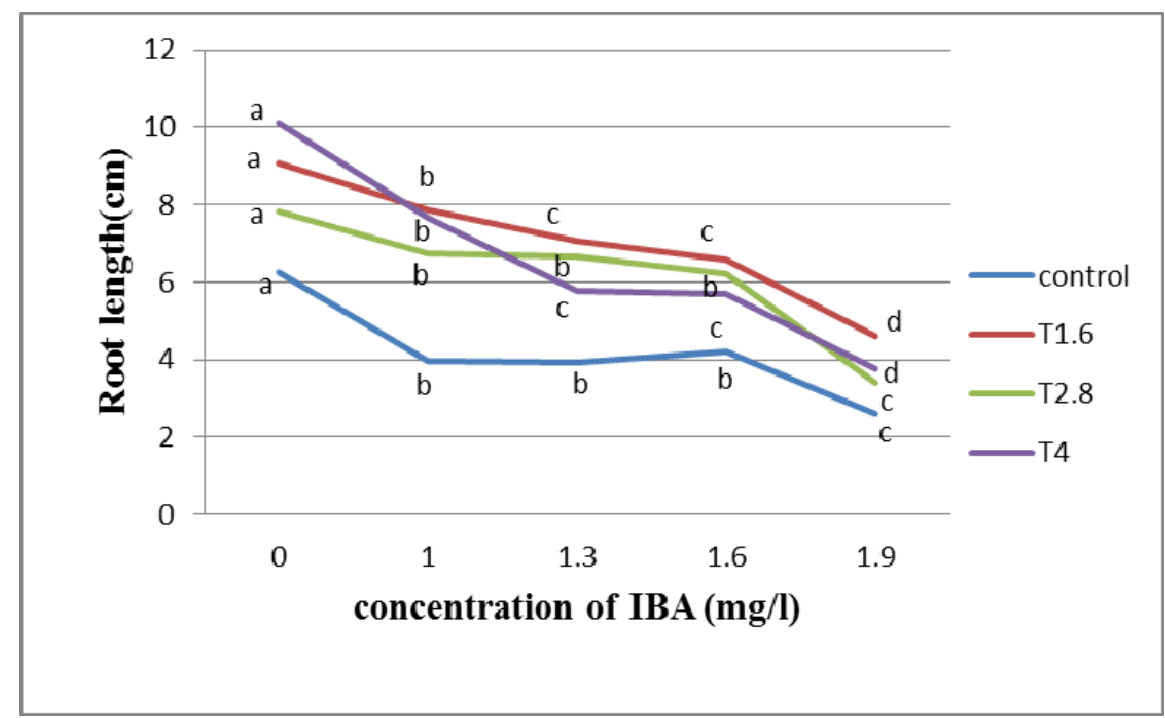

Figure 7. The Effect of thiamine and IBA on root length of GF677 